\title{
ON THE ULTIMATE VALUES OF DEFORMATION ANGLE FOR REINFORCED CONCRETE COLUMNS
}

\author{
By Takayuki SHIMAZU*, Member of A.I.J.
}

\section{Introduction}

Deformation capability of structural components is one of the most important factors in seismic safety of buildings. Since the Tokachiko earthquake attacked northern Japan in 1968, considerably numerous experiments on reinforced concrete columns have been conducted at the various institutes in Japan, including the synthetic projects initiated from 1972 with the proposal of the Building Research Institute of the Ministry of Construction. The quantitative understandings have, however, not yet been sufficient due to the complicated resistance characteristics of reinforced concrete columns. The aim of this study is to clarify the relationship between the deformation capability of reinforced concrete columns and the various parameters, such as hoop reinforcement ratio, longitudinal reinforcement ratio, shear span ratio or axial load level applied, by using the test results mentioned above.

In the experimental works of the synthetic projects mentioned above, most of column specimens were subjected to about fifty times reversals of horizontal load until failure to obtain the hysteretic loop characteristics at each cycle of a given deflection amplitude. Also in these projects, the ultimate value of deformation angle has been proposed as an index representing the deformation capability of reinforced concrete columns. The value means the useful ultimate or useful limit of deformation angle and was defined as the deformation angle when the first load of cyclic loading at a given deflection amplitude detriorated less than $80 \%$ of maximum load or when the tenth load detriorated less than $50 \%$ of the maximum load as shown in Fig. $1 \mathrm{~A}$ and $\mathrm{B}$ respectively. This definition is due to the fact that from the deformation angle when the first load detriorates less than $80 \%$ of the maximum load, the load decreases remarkably with the loops unstable and the criterion that loops can be regarded to be unstable when the tenth load detriorates

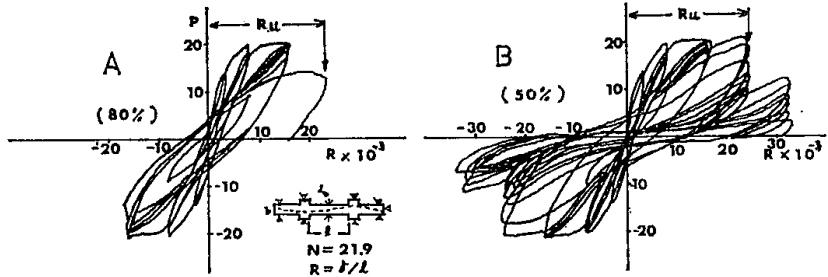

Fig. 1 Load-deflection curves illustrated, regarding the definition for the ultimate values of deformation angle (Ref. 12)

less than $50 \%$ of the maximum load even if the first load is not less than $80 \%$ of the maximum load. Thus the ultimate value of deformation angle defined is summarized to correspond to that of the amplitude from which the loops become unstable. It should be also added that amplitudes are discrete quantities given by each investigator although usually given in a regular way with multiples of an unit amplitude.

In this paper the ultimate value defined here is statistically examined, by including the test results of the investigations other than those of the synthetic projects. Total number of the specimens used in this study was about two hundreds and six(y) ${ }^{1 / 17}$.

\section{Variables influencing the deformation capability of columns}

The ultimate deformation angle is influenced by various parameters, such as axial load level, shear span ratio, longitudinal reinforcement ratio etc. as well as hoop reinforcement ratio. In Table 1 are shown the ranges of these parameters, used in the experiments mentioned above. It can be readily presumed that the size of columns, the kind of hoops (spiral, subtie-type or conventional) or the kind

* Assoc. Professor, University of Hiroshima Dr. of Eng. 
Table 1 Ranges of each variable in specimens

\begin{tabular}{|c|c|c|c|c|c|}
\hline Shear span ratio ad & 1.0 & 1.5 & 2.0 & 2.5 & 3.0 \\
\hline Number of specimens & 33 & 39 & 131 & 27. & 33 \\
\hline Axial load ratio $\eta_{0}$ & $0.056-0.254$ & $0.078 \sim 0.274$ & $0.056-0.330$ & $0.084 \sim 0.330$ & $0.110 \sim 0.284$ \\
\hline Lon8. rein ratio $P_{t}(\%)$ & $0.31 \sim 0.95$ & $0.34 \sim 1.24$ & $0.31 \sim 1.275$ & $0.34 \sim 1.00$ & $0.34 \sim 1.24$ \\
\hline Hoop rein ratio $P_{w}(\%)$ & $0.20 \sim 2.39$ & $0.15 \sim 2.12$ & $0.09 \sim 2.44$ & $0.18 \sim 1.30$ & $.0 .09 \sim 1.15$ \\
\hline Concrete strength Fc( & $210 \sim 473$ & $124 \sim 277$ & $124 \sim 473$ & $205 \sim 233$ & $185 \sim 292$ \\
\hline Steel yield Long. & $3.000 \sim 4281$ & $3,332 \sim 4,180$ & $3220 \sim 4,281$ & $3,660 \sim 4,230$ & $4020 \sim 5.180$ \\
\hline strengths $0_{y}\left(k x^{\prime \prime} \mid H_{0 o p}\right.$ & $2,960 \sim 3,930$ & $2,960 \quad 4,635$ & $2,798 \sim 5.200$ & $2,890 \sim 4.110$ & $2890 \sim 3770$ \\
\hline Section & $20-50$ & $15 \sim 48$ & $\sim 50$ & $\sim 45$ & $20-25$ \\
\hline Shear span a (cm) & $20 \div 50$ & $22.5 \div 72$ & $40 \sim 100$ & $\sim 112.5$ & $60 \sim 70$ \\
\hline
\end{tabular}

of longitudinal reinforcement bars (plain or deformed), or the number of cycles of reversal loads influence the deformation capability. In this paper, however, only four variables, axial load level, shear span ratio, longitudinal reinforcement ratio as well as hoop reinforcement ratio are considered mainly, in order to obtain fundamental information. on the deformation capability.

It should be noted herein that columns are in general designed so that flexural yielding preceedes before shear failure in calculation. According to the design formula of the Reinforced Concrete Building Code Requirements and Commentary of AIJ (1970 or 1979) ${ }^{18) ~ 19)}$, the calculated value for flexural yield is obtained as follows when axial load level is lower than that at balanced conditions.

$$
M_{r}=0.8 a_{t} \cdot \sigma_{y} \cdot D+0.5 \eta_{0}\left(1-\eta_{0}\right) F_{c} b D^{2}
$$

in which $a_{t}, \sigma_{y}, F_{c}, b, D$ and $\eta_{0}$ are the area and yield strength of longitudinal reinforcement, concrete strength, width and depth for concrete section and axial load level applied $\left(N / F_{c} b D\right)$ respectively, as shown in Fig. 2. On the other hand the following equation, called modified Ōhno-Arakawa equation ${ }^{20)}$ is commonly used for estimating the shear capacity of reinforced concrete columns.

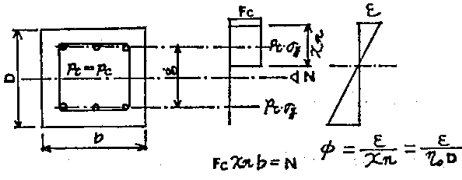

Fig. 2 Equilibrium in section at ultimate (Ref. 19)

$$
Q_{s}=\left(0.90+\frac{\sigma_{0}}{250}\right)\left\{k_{u} k_{p} \frac{0.115}{M / Q d+0.115}\left(180+F_{c}\right)+2.7 \sqrt{p_{w w} \sigma_{y^{\prime}}}\right\} \cdot b j
$$

in which $d, j, M / Q$ and $\sigma_{0}$ are effective depth, lever arm of the internal couple (7/8d), shear span ratio (a) and axial stress $(N / b D)$ while $P_{w},{ }_{s} \sigma_{y}$ and $k_{u}, k_{p}$ are the ratio and yield strength of hoop reinforcement and coefficients dependent on $d$ and $p_{t}$, respectively. In the Eq. (2), $\mathrm{kg} / \mathrm{cm}^{2}$ is needed to use as unit for the $\sigma_{0}, F_{c}$ and $w_{w}$ values and $\sigma_{0}$ is needed not to be greater than $100 \mathrm{~kg} / \mathrm{cm}^{2}$. The $k_{u}$ and $k_{p}$ values are given in Fig. $3 \mathrm{~A}$ and $\mathrm{B}$, cited from Ref. 18, respectively. In the tests the equations used to calculate flexural strength for columns specimens can be regarded to have been Eq. (1) but those for shear strength were not always the Eq. (2). Most of specimens were designed for shear strength with Arakawa's minimum equation ${ }^{18), 21)}$, similar to Eq. (2) but lacking in the item regarding axial stress and with a little modification. It is however, clear that Eq. (2) is more appropriate in estimating the ultimate shear strength of columns because of taking into account the effects of axial load. Thus the levels of shear capacity to flexural $\left(Q_{s} / Q_{m}\right)$ were calculated for all. the specimens, using Eq. (1) and Eq. (2). In Fig. 4 are shown the ranges of the values of $Q_{s} / Q_{m}$ for each shear span ratio of $1-3$. In Fig. 5 is also illustrated the distribution of the $Q_{s} / Q_{m}$ values for the shear span ratio of 2 , with tested strength to calculated values $\left(Q_{\max } / Q_{m}\right)$ being set as ordinate. It can be concluded from these figures that calculated shear strength is not less than calculated flexural strength for all the columns used in the experiments except several specimens.

3 Dexivation of equation for estimating the ultimat values of deformation angle
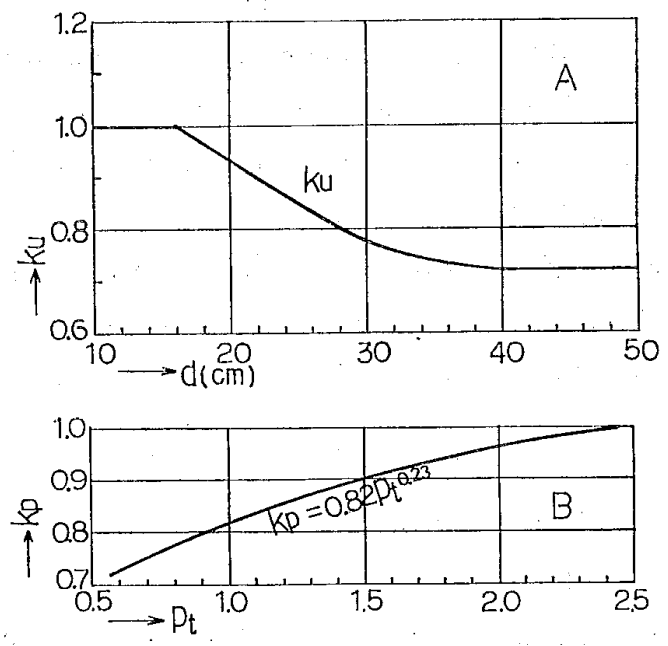

Fig. $3 k_{u}$ and $k_{p}$ values (from Ref. 18) 


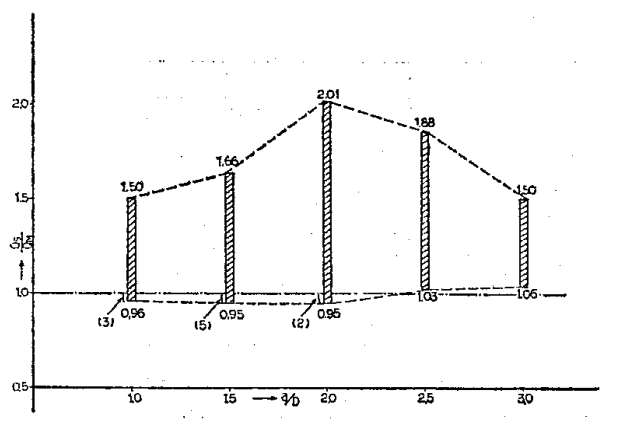

Fig. 4 Ranges of calculated values of shear to flexural capacity for each shear span ratio

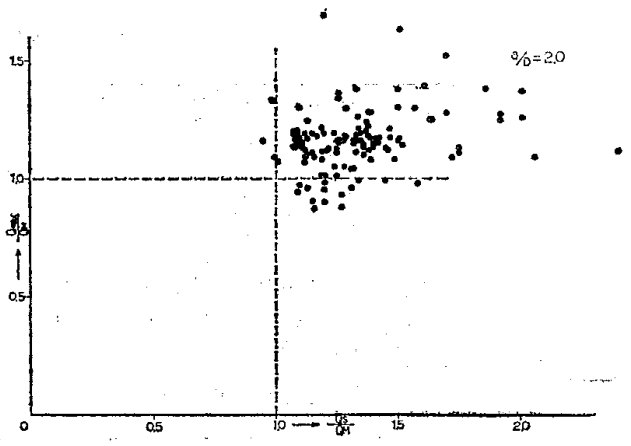

Fig. 5 Distribution of tested to calculated values on. maximum loads versus $Q_{s} / Q_{m}$ values $(a / D=2.0$ )

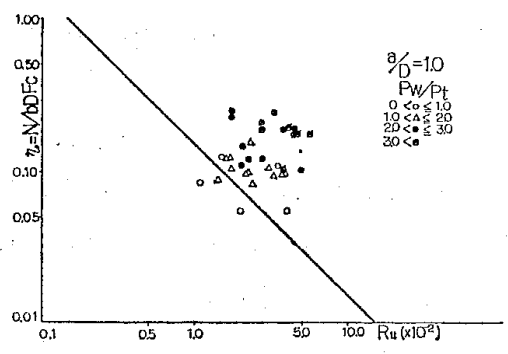

(a) $a / D=1.0$

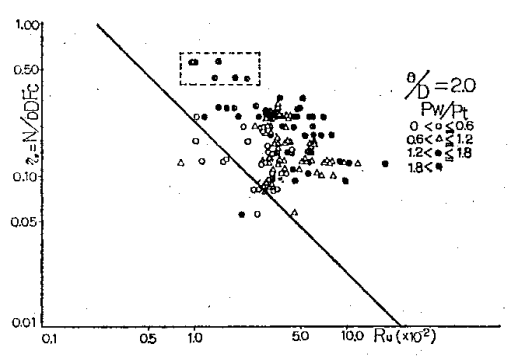

(b) $a / D=2.0$

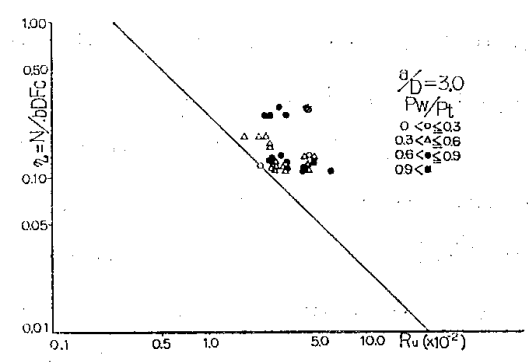

(c) $a / D=3.0$

Fig. 6 Axial load levels versus ultimate values of deformation angle

In Figs. 6 (a)-(c) are plotted the tested values regarding the deformation capability, the ultimate values of deformation angle $R_{u}$ as defined above, versus the axial load level applied, in the three groups of the same shear span ratio. It can be seen from these figures that $R_{u}$ values are not less than $10^{-2}$ rad. if flexural yielding preceedes as mentioned above, although each range of the variables dealt with herein should be taken into account. These plotted points are classified according to the values of the ratio of hoop reinfor-cement to longitudinal $\left(p_{w} / p_{t}\right)$ in each figure. It is found that the deformation capability values, as a whole, increase with lower values of $\eta_{0}$ and with higher values of $p_{w} / p_{t}$. It should be commented herein that little systematic relationships have been found between deformation capability and hoop reinforcement ratio alone, as shown later. This seems due to the fact that the higher values of shear are developed for the columns with higher values of longitudinal reinforcement, indicating that higher hoop reinforcement is needed to obtain sufficient deformation capability for these columns. In each of Fig. 6 (a) $\sim$ (c) is shown a line, indicating a lower bound for the $R_{u}$ values of plotted points. These lines are obtained from the following three assumptions regarding ultimate conditions $^{22), 23)}$.

(1) The length of yielding region (critical region) equals to $D$, depth of section.

(2) The average curvature in this region is $\varepsilon / \eta_{0} D$.

(3) The ultimate concrete compressive strain $\varepsilon$ is 0.003 .

The first assumption was adapted from the the fact that flexural-shear cracks of column specimens are mostly observed to concentrate on the region of the length equal to the depth at ultimate. The second came from the same assumption with that used for the Eq. (1) mentioned above. The depth ratio of neutral axis equals to the value of $\eta_{0}$ as shown in Fig. 2. The third is that commonly used. From these assumptions and by referring to Fig. 7, the following can be derived as an equation estimating the ultimate value of deformation angle for the columns without hoop reinforcement.

$$
R_{u}=\frac{0.003}{\eta_{0}}\left(1-\frac{D}{2 a}\right)
$$

This type of expression will be more generalized later on, by considering the effects of the value of $\sqrt{p_{w} / p_{t}}$. In this paper the ranges of the axial load load level dealt with are about $0.07-0.33$ as shown in Figs. 6 (a) $\sim(\mathrm{c})$, as well as in Table 1. Further studies

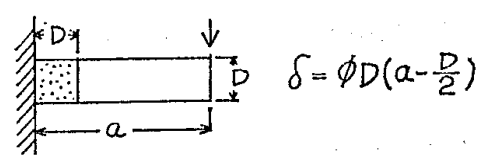

Fig. 7 Relationship between deformation and unit curvature 
are needed for the cases of lower values of $\eta_{0}$, including beams although it has been experimentally reported $^{24)}$ that the coupled resistance by both the compression and tension reinforcement is extremely ductile unless the buckling or tensile rupture occurs in the reinforcement, just as the Eq. (3) suggests. On the other hand, experimental works have been made for the cases of $\eta_{0}$ values higher than 0.33 , as the test results ${ }^{25}$ ) are illustrated in Fig. 6 (b). In this paper, these high ranges of axial load level is, however, excluded for discussion because of the limited number of test results as well as the limitati on of the applicability of Eqs. (1) and (2).

The differences of horizontal distance between the tested values and the lines of Eq. (3) in Figs. 6 (a) ( c) were plotted, using the values of $p_{w}$ and $p_{t}$. The plottings against the values of $p_{w}$ alone as abscissa have been, first, made but little systematic relationships have been found as illustrated in Figs. 8 (a) and (b). Second, $p_{w} / p_{t}$ values have been used as abscissa under the consideration of the effects of shear level developed as explained above. It is found from Figs. 9 (a) and (b) that there exist, to some extent, systematic trends and that most of plotted values lie in each strip indicated in each figure. The $p_{w} / p_{t}$ values at the starting of the effects, which are around 1.0 and 0.25 for the shear span ratios 1.0 and 2.0 respectively, can be related to those at the coincidence of fexural and shear capacities, determined by Eqs. 1 and 2. It is also interesting to note that the upper limit of the effects is nearly the same in both the figures although the effect rate due to hoop reinforcement is much faster for the shear span ratio of 2.0 than for that of 1.0. By referring to these figures and using $\sqrt{p_{w} / p_{t}}$ values as abscissa, Figs. 10 (a) $\sim$ (e) have been finally made. The $\sqrt{p_{w} / p_{t}}$ values can be regarded to be the equivalent diameter ratios of hoop to longitudinal reinforcement since $p_{w} / p_{t}$ values are approximately the ratios of area of both the reinforcement. From Figs. 10 (a) (e), the intermediate trend between the shear span ratios of 1 and 2 can be traced as that of the shear span ratio of 2 , regarding the shear ratios of 2.5 and 3.0.

Each solid line in Figs. 10 (a) $\sim$ (e) was determined as a simple expression representing the average

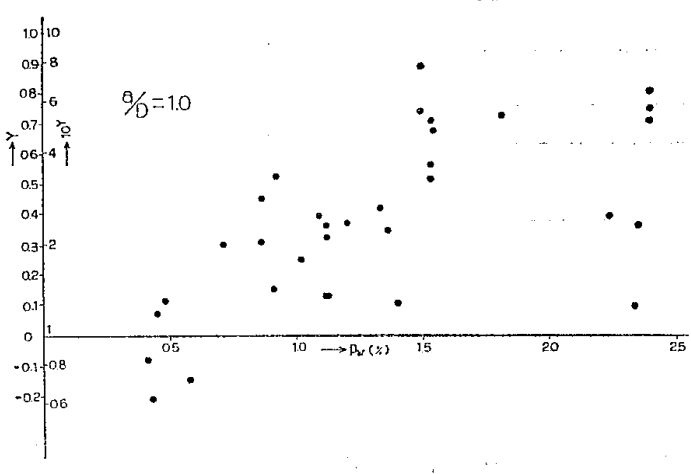

(a) $a / D=1.0$

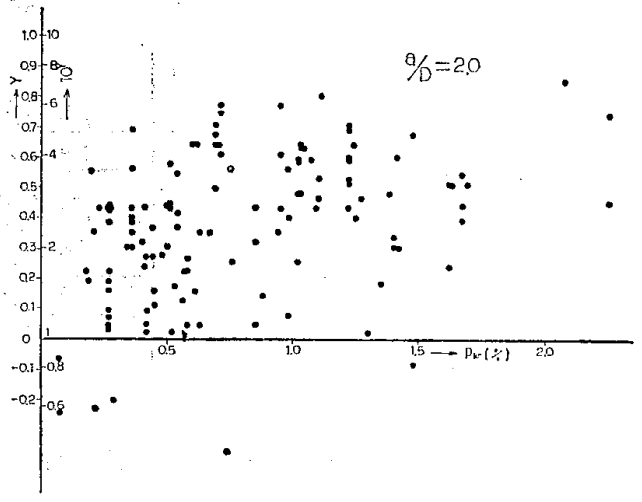

(b) $a / D=2.0$

Fig. 8 Logarithmic values of the effect due to $p_{w}$ values alone

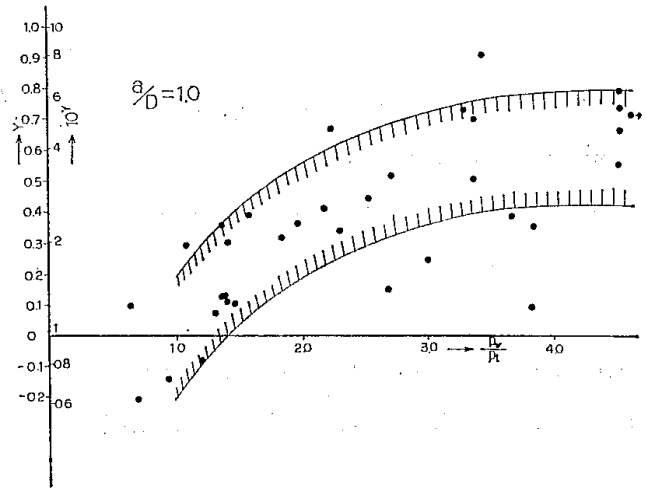

(a) $a / D=1.0$

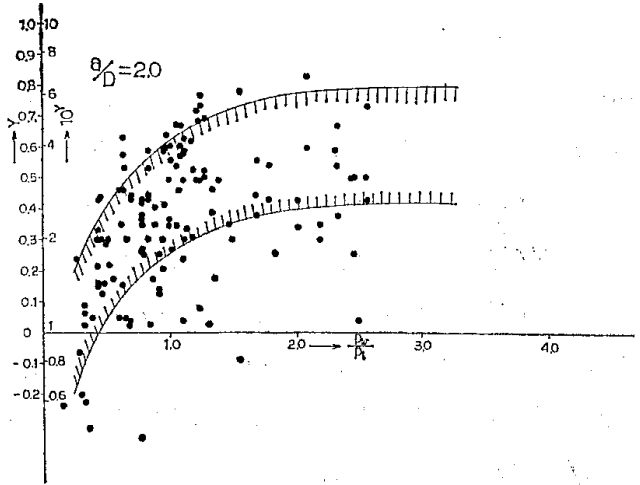

(b) $a / D=2.0$

Fig. 9 Logarithmic values of the effect due to $p_{w} / p_{t}$ values 


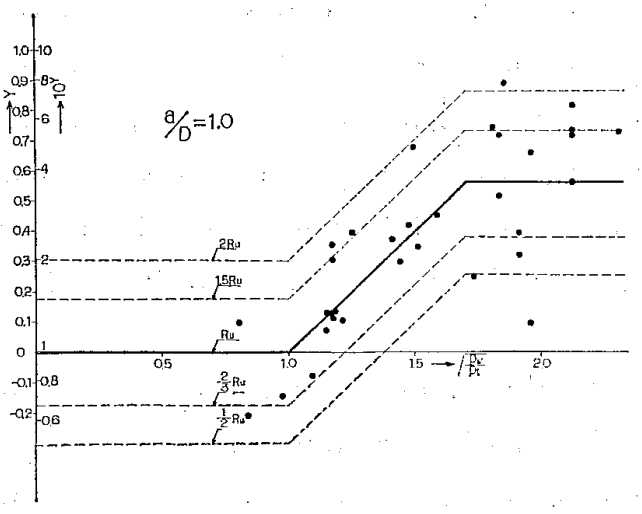

(a) $a / D=1.0$

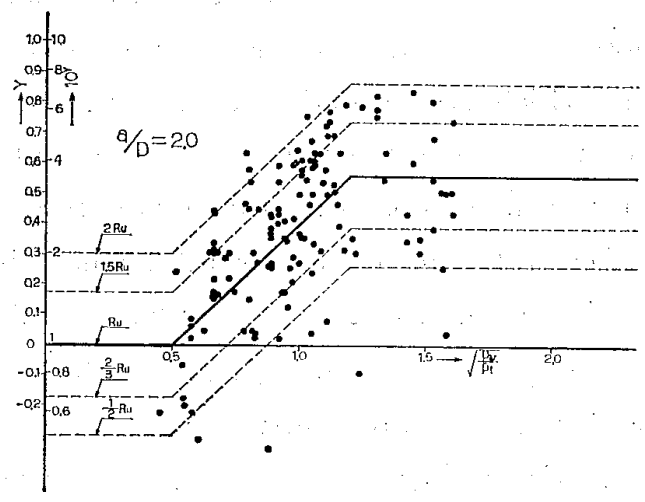

(c) $a / D=2.0$

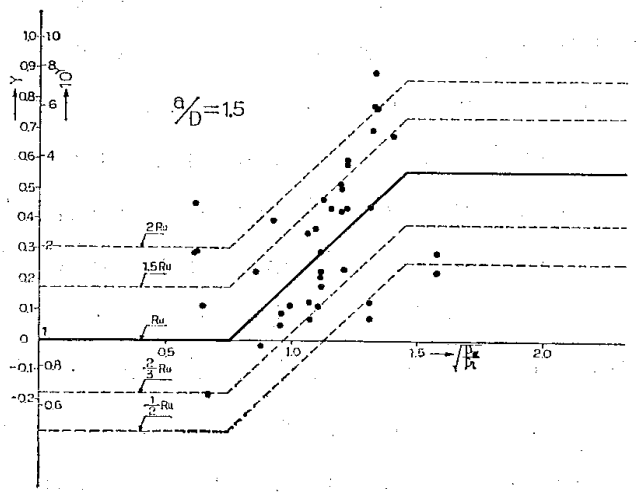

(b) $a / D=1.5$

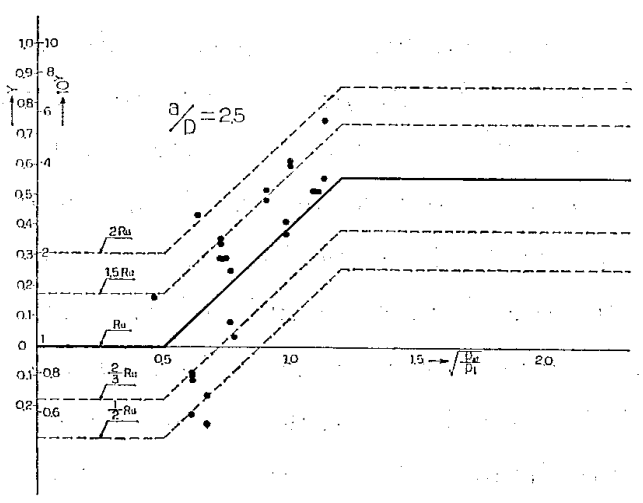

(d) $a / D=2.5$

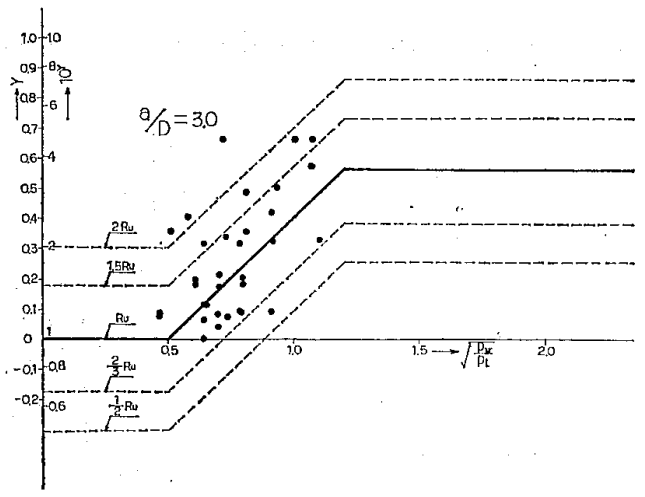

(e) $a / D=3.0$

Fig. 10 Logarithmic values of the effect due to $\sqrt{p_{w} / p_{t}}$ values

line for plotted values. The effects of $\sqrt{p_{w} / p_{t}}$ consist of three steps for all shear ratios, as follows.

$$
\begin{aligned}
& Y=0 \\
& Y=0.8\left(\sqrt{p_{w} p_{t}}-S\right) \\
& Y=0.56 \text {. }
\end{aligned}
$$

in which $S$ is the $\sqrt{p_{w} / p_{t}}$ value at which Eq. (5) starts and can be expressed together with $\sqrt{p_{w} / p_{t}}$ value $E$ of the ending point of Eq. (5), as follows for each shear span ratio.

$$
\begin{aligned}
& S(E)=1.0(1.7) \text { for } a / D=1.0 \cdots \\
& S(E)=0.75(1.45) \text { for } a / D=1.5 \\
& S(E)=0.50(1.2) \text { for } a / D \geqq 2.0
\end{aligned}
$$

The $S$ and $E$ values for $a / D=1.5$ were determined at the middle between those for $a / D=1.0$ and 2.0, as shown above. It should be added that Eq. (4) is little used since flexural yielding usually preceedes around $\sqrt{p_{w} / p_{t}}$ values of $S$.

By using the Eq. (3) and considering that the effects of Eq. (4) $\sim(6)$ are logarithmic values, the following can be obtained as an expression for estimating the ultimate values of deformation angle, 
including the effects of $\sqrt{p_{w} / p_{t}}$ values.

$$
R_{u}=\frac{0.003 \cdot 10^{Y}}{\eta_{0}}\left(1-\frac{D}{2 a}\right)
$$

However this means an expression for the average lines about plotted points as shown in Figs. 10 (a) $\sim(\mathrm{e})$. By shifting the average lines in these figures vertically downwards as shown with dotted lines each, the following two expressions can be obtained as conservative one and very conservative one respectively.

$$
\begin{aligned}
R_{u} & =\frac{0.002 \cdot 10^{Y}}{\eta_{0}}\left(1-\frac{D}{2 a}\right) \\
\cdots \cdots \cdots \cdots \cdots \cdots \cdots \cdots \cdots \cdots \cdots \cdots \cdots \cdots \cdots \cdots \cdots & (11 \\
R_{u} & =\frac{0.0015 \cdot 10^{Y}}{\eta_{0}}\left(1-\frac{D}{2 a}\right)
\end{aligned}
$$

\begin{tabular}{|c|c|c|c|c|c|c|c|c|}
\hline & \multicolumn{5}{|c|}{ Shear span ratio } & \multirow{2}{*}{\begin{tabular}{|l|} 
Total \\
Num.
\end{tabular}} & \multirow{2}{*}{$\begin{array}{l}\text { Total Num } \\
\text { ratio }(\%)\end{array}$} \\
\hline & & 1.0 & 1.5 & 2.0 & 2.5 & 3.0 & & \\
\hline \multirow[t]{2}{*}{ Equation (11) } & Num. & $\frac{6}{33}$ & $\frac{5}{39}$ & $\frac{21}{131}$ & $\frac{5}{27}$ & $\frac{2}{33}$ & $\frac{39}{263}$ & 14.8 \\
\hline & $(\%)$ & (18.2) & $(15.6)$ & $(16.0)$ & (18.5) & $(6.6)$ & & \\
\hline \multirow{2}{*}{ Equation (12) } & Num. & $\frac{1}{33}$ & $\frac{3}{39}$ & $\frac{7}{131}$ & $\frac{1}{27}$ & $\frac{0}{33}$ & $\frac{12}{263}$ & 4.6. \\
\hline & $(\%)$ & $(3.0)$ & $(7.7)$ & $(5.3)$ & (3.7) & $(0)$ & & \\
\hline
\end{tabular}

Table 2 Numbers and percentages of the specimens having $R_{u}$-values below Eqs.. (11) and (12)

The total number ratios of the specimens which lie below the Eq. (11) and Eq. (12) are about $14.8 \%$ and $4.6 \%$ respectively as shown in Table 2 with each shear span ratio. It is interesting to note that the coefficient values, 0.002 and 0.0015 , of these expressions are those of strain at maximum stress for ordinary concrete cylinders, instead of ultimate strain 0.003 and that the term of $10^{Y}$ can be also regarded as a factor increasing these three strains; depending upon the values of $\sqrt{p_{w} / p_{t}}$.

It should be added herein that the variables other than the four main variables examined in this paper, such as type of hoops (spiral, subtie, closed-type or conventional), level of shear capacity to flexural, difference of definitions for the ultimate values of deformation angle (first cycled-80\% or tenthcycled-50\% explained in the Introduction), kind of longitudinal and hoop reinforcement (plain or

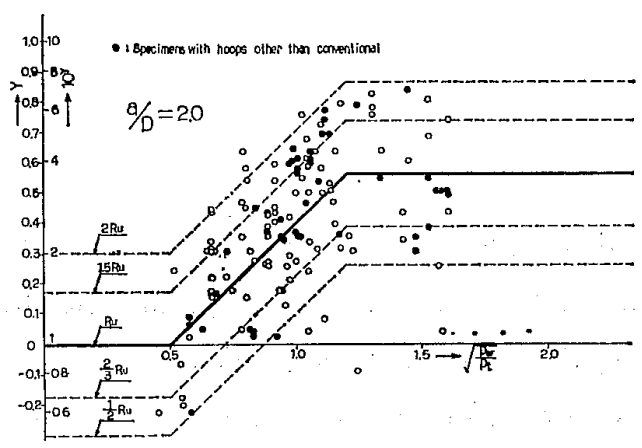

Fig. 11 Logarithmic values of the effect due to the $\sqrt{p_{w} / p_{t}}$ values, classified by the types of hoops $(a / D=2.0)$

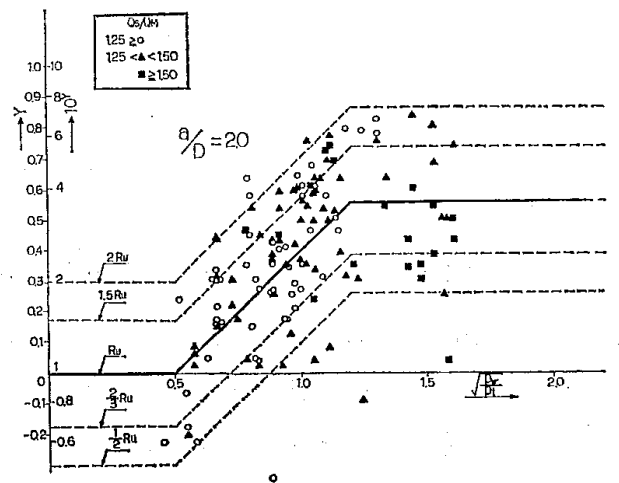

Fig. 12 Logarithmic values of the effect due to the $\sqrt{p_{w} / p_{t}}$ values, classified by the levels of $Q_{s} / Q_{m}$ values $(a / D=2.0)$

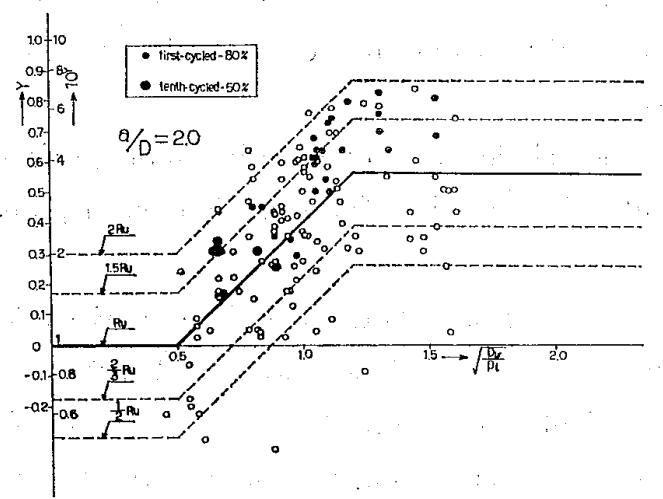

Fig. 13 Logarismic values of the effect due to the $\sqrt{p_{w} / p_{t}}$ values, illustrated by the definition of the ultimate values of deformation angle $(a / D=2.0)$ 


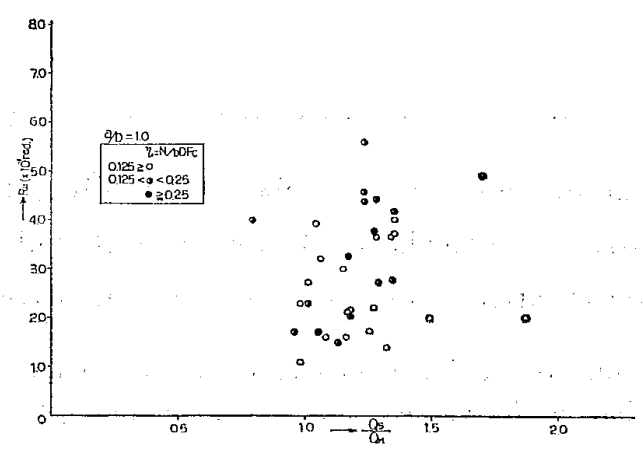

(a) $a / D=1.0$

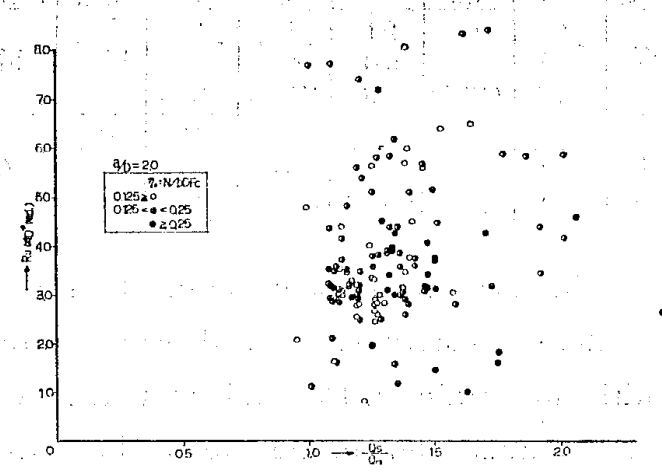

(c) $a / D=2.0$

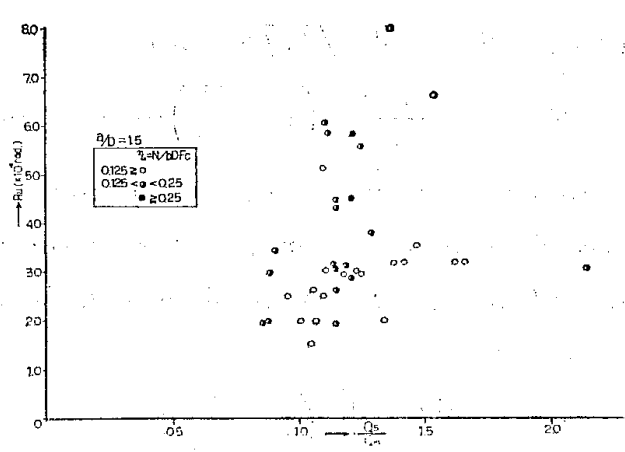

(b) $a / D=1,5$

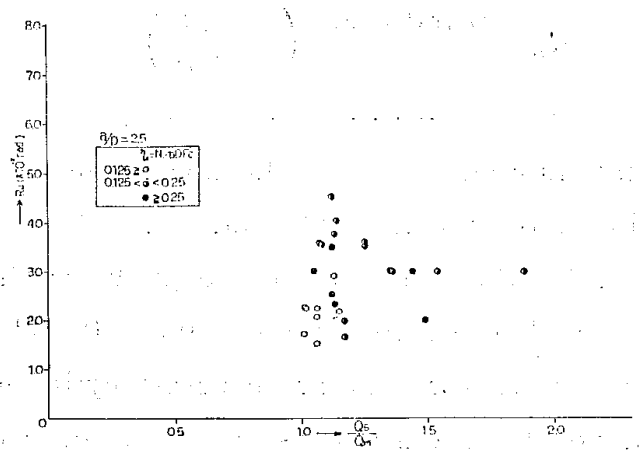

(d) $a / D=2.5$

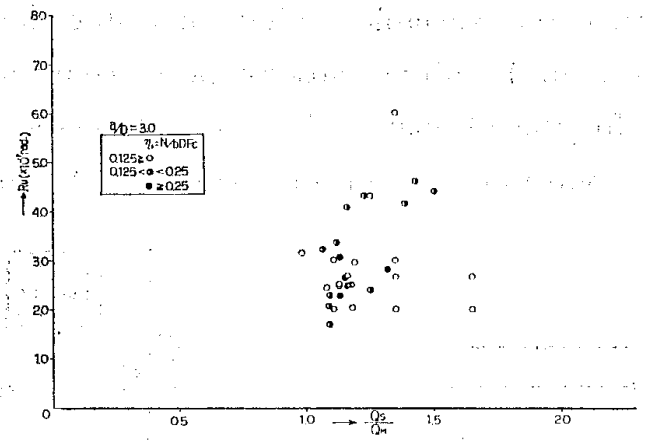

(e) $a / D=3.0$

Fig. 14 Distribution of ultimate values of deformation angle versus $Q_{s} / Q_{m}$ values

deformed) or number of reversals of loads are also examined to find the causes of spread distributions in Figs. 10 (a) $\sim(\mathrm{e})$, as illustrated in Figs. 11 13. However, definite conclusions have not been drawn regarding the effects of these variables on the ultimate values of deformation angle, the examinations still being continued. In Figs. 14 (a) (e), are also plotted the direct values of ultimate deformation angle using $Q_{s} / Q_{m}$ values as abscissa. It can be seen from these figures that there exist little systematic relationships. The $Q_{s} / Q_{m}$ value is only a factor to determine the border of failure mode, flexural or shear. The deformation characteristics seem to be predominated by the resistance mechanism of the one side. In other words, $Q_{s} / Q_{m}$ value seems to be insensible to the ultimate values of deformation angle even if there exist its effects.

Furthermore, deformation characteristics are essentially more affected by various uncertain factors than strength. Thus it is concluded herein that for seismic design point of view, the Eq. (12) is recommended to use.

4 Comparisons with the expression suggested in the Reinforced Concrete Building Code Requirements and Commentary of AIJ (1971 or 1979)

In the commentary of Article 15 of Sect. (pp. 166-1979 ed.) the following expression is suggested to estimate the ultimate values of deformaion angle for reinforced concrte columns, by changing the symbols into those of this paper,

$$
R_{2 l}=\frac{1}{3} \frac{0.8_{s} \varepsilon_{c}}{\eta_{0}-0.08}\left(\frac{a}{D}\right)
$$


This was derived by assuming the unit curvature of the critical section as follow: $\mathrm{s}^{26)}$.

$$
\frac{1}{\rho_{0}}=\frac{{ }_{s} \varepsilon_{c}}{x_{1}-d_{c 1}}=\frac{0.8{ }_{s} \varepsilon_{c}}{\eta_{0}-0.08}
$$

in which ${ }_{s} \varepsilon_{c}, x_{1}$ and $d_{c_{1}}$ are ultimate compression steel strain, neutral axis ratio obtained by assuming that concrete stress block $0.8 F_{c} b x_{1} D$ equals to axial load $N$, under the consideration that both the compression and tension steels yield at ultimate and compression steel depth ratio assumed as 0.1 , respectively. Thus Eq. (13) can be obtained by assuming curvatures distribution along column length as linearly.

In Fig. 15 are compared both the trends of Eq. (3) and Eq. (13) in which the ultimate compression steel strain is assumed as 0.003 , for $a / D=2.0$ and 3.0. It is found that both the Eqs. give the similar $R_{u}$ values above the axial load level of about 0.2 but that the trends become quite different below the axial load level of 0.1. In Fig. 15 are also shown the tested values cited from the Code. The definition used as ultimate value of deformation angle; for these tested values is quite different from that of this paper

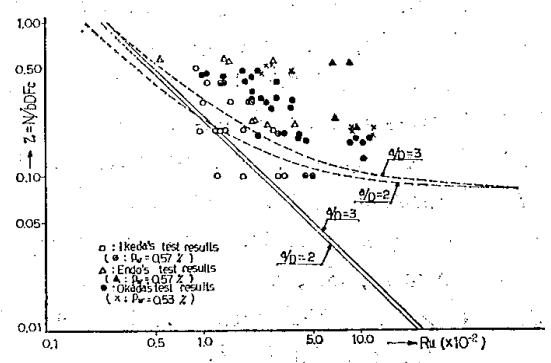

Fig. 15 Comparison of Eq. (3) and Eq. (13) and the reversals of load for specimens only within several cycles. In these tests, the ultimate value of deformation angle was defined as that at final failure, commonly at the buckling of compression steel. It is found from Fig. 15 that Eq. (3) can be lower bound even for the tested values from the Code. In the Eq. (13) the effects of hoop reinforcement ratio etc. are not formulated quantitatively; different from the Eqs. (10) (12) and it is doubtful that strain at the buckling of compression steel can be determined definitely. Thus it is concluded that the Eq. (10) and Eq. (12) are much more appropriate as average and minimum expressions in estimating the ultimate values of deformation angle, respectively than the Eq. (13) based on the insufficient data at that time.

\section{Conclusions}

Based on the studies reported herein, the following conclusions can be drawn.

1) Equations were proposed for estimating the ultimate values of deformation angle for reinforced concrete columns subjected to multi-reversals of horizontal load, through the analyses of the tested results by various investigations, by taking into account the effects of hoop and longitudinal reinforcement ratios, shear span ratio as well as axial load level. The equations have been also compared with that suggested in the Code of AIJ.

2) Further researches are needed to clarify the effects of the various parameters other than those dealt with herein, such as; kind of hoops (spiral, subtie, or conventional hoop), etc., and also to extend the equations for columns with axial load levels outside the range of $0.07 \sim 0.33$, which is dealt with in this paper.

\section{Acknowledgements}

This study has been conducted in the University of Hiroshima and the author acknowledges the hearty encouragement of Prof. M. Matsuura and thanks N. Zoneya, an assistant for his help in this data analysis work.

\section{References}

1) Arakawa, T., Takeda, H., Yonezawa, T., and Matsuka, Y.; Abstracts of the Annual Convention of Architectural Institute of Japan, Oct. 1974, pp. 1339-40, Oct., 1975, pp. 1111-12, 1117-18 and Oct. 1976, pp. 1415-16

2) Fukada, Y.; Abst. of the Ann. Con. of AIJ, Oct. 1975, pp. 1119-20 and Oct. 1976, pp. 1413-14

3) Fukuzawa, R., Chiba, Y., Kondo, N., and Yanagishita, K.; Abst. of the Ann. Con. of AIJ, Oct., 1974, pp. 1311-12

4) Higashi, Y., Okubo, Z., and Otsuka, M. ; Abst. of the Ann. Con. of AIJ, Oct. 1975, pp. 1113-14

5) Hirosawa, M., Nakazawa, M., Shimizu, Y., Takahashi, H. and Kumagai, K. ; Abst. of the Ann. Con. of AIJ, Oct. 1977, pp. 1501-02 and Sep. 1978, pp. 1747-48

6) Kano, Y., Endo, T. and Kato, H. ; Abst. of the Ann. Con. of AIJ, Oct. 1973, pp. 1425-26

7) Kokusho, S., Hirosawa, M., Fukuhara, M., Hayashi, S., Yanagishita, K., Iwashita, S., Yamaguchi, M., and Nagaoka, T. ; Abst. of the Ann. Con. of AIJ, Oct. 1973, pp. 1393-94, 1401-02, 1423-24 
8) Nakata, S., and Sato; K. ; Abst. of the Ann. Con. of AIJ, Oct. 1976, pp. 1411-12

9) Omori, S., Takahashi, T., Ishii, K., and Watanabe, S. ; Abstr. of the Ann. Con. of AIJ, Oct. 1974, pp. 1313$14,1341-42$

10) Ozaki, M., Taga, A., Eguchi, K., Maeda, Y. and Fujisawa, M. ; Abst. of the Ann. Con. of AIJ, Oct. 1975, pp. 1089-90

11) Saito, T., Yosida, S. and Nishigaki, T.; Abst. of the Ann. Con. of AIJ, Oct. 1973, pp. 1423-24

12) Sgano, S., Tobata, Y., Hoshino, N., Yamaguchi, I., and Oi, Y.; Abst. of the Ann. Con. of AIJ, Oct. 1973, pp. 1391-92

13) Takada, S., Nagai, Y., Yamagata, Y., Karatsu, T., Sakakibara, H., Inoue, T. and Moriwaki, Y.; Abst. of the Ann. Con. of AIJ, Sep. 1979, pp. 1253-54

14) Takeda, T., Nakayama, T., Yoshioka, K., Koike, K. and Kikuchi, T.; Abst. of the Ann. Con. of AIJ, Oct. 1974, pp. 1307-08, Oct. 1975 , pp. 1087-88 and Oct. 1977, pp. 1495-96

15) Tanaka, R. ; Abst. of the Ann. Con. of AIJ, Sep. 1978, pp. 1767-68

16) Wakabayashi, M., Sasaki, R., Minami, K. and Asai, Y. ; Abst. of the Ann. Con. of AIJ, Sep. 1978, pp. 1375-76

17) Yamamoto, K. ; Abst. of the Ann. Con. of AIJ, Oct. 1976, pp. 1391-92

18) Architectural Institute of Japan ; Reinforced concrete buildings code requirements and commentary (1979)

19) Sugano, S. ; Concrete journal of Concrete Institute of Japan, Vol. 11, No. 2, Feb. 1973, pp. 1-9

20) Ōno, K., Shibata, T., Hattori, T., Imano, S., Owada, S., and Saito, Y. ; Abst. of the Ann. Con. of AIJ, Oct. 1972, pp. 1091-92

21). Arakawa, T.; Concrete journal of Concrete Institute of Japan, Vol. 8, No. 2, Jul. 1970, pp. 11-20

22) Corley, W.G. ; Journal of ASCE ST 5, Oct. 1966, pp. 121-146

23) Mattock, A.H. ; Journal of ASCE ST 2, Apr. 1967, pp. 519-522

24) Kent, D.C., and Park, R. ; Journal of ASCE ST 7, Jul. 1971, pp. 1969-90

25) Higashi, Y., Okubo, Z., and Iso, K. ; Abst. of the Ann. Con. of AIJ, Oct. 1977, pp. 1497-98

26) Miyatake, T., and Sugita, K. ; Proc. of the Kanto Branch Symposium of AIJ, May. 1964, 1964, pp. 93-96

\section{Appendix}

ultimate values of deformation angle used in the References (1) (17)

App. Table 1 (a)

\begin{tabular}{|c|c|c|c|c|c|c|c|c|c|c|c|}
\hline$y$ & No. & $\mid \begin{array}{c}D \\
(C \mathrm{~m})\end{array}$ & $\mid \begin{array}{l}2 a \\
(\mathrm{~cm})\end{array}$ & {$\left[\begin{array}{c}F c \\
k g k n\end{array}\right.$} & 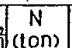 & {$\left[\begin{array}{l}p_{i} \\
(\%)\end{array}\right]$} & & $\mathrm{p}_{w}(\%)$ & $\left(\begin{array}{c}\mathrm{Ru} \\
\left(\times 0^{-2}\right)\end{array}\right.$ & $\begin{array}{l}\text { Hoop } \\
\text { Type }\end{array}$ & \begin{tabular}{|l|l|} 
Shear \\
Eout
\end{tabular} \\
\hline \multirow{5}{*}{$\begin{array}{l}\text { Ret:1 } 1 \\
\text { (a) }\end{array}$} & & & & & & & $\mid 0.21$ & 0.56 & & & \\
\hline & 1 & & 50 & 203 & 12.5 & 0.34 & 0.26 & 0.60 & 1.08 & & Ohn. \\
\hline & 1 & 25 & 75 & $s$ & 250 & 0.61 & 0.34 & 0.71 & 1 & Su. & " \\
\hline & 25 & & 100 & 264 & 37.5 & 0.95 & 0.43 & 1.20 & 3.54 & & " \\
\hline & s & & & & & & 0.52 & 1.33 & & & ", \\
\hline \multirow{3}{*}{ (b) } & 26 & & 100 & 209 & 12.5 & 0.34 & 0.18 & 0.35 & 1.54 & & " \\
\hline & 13 & 25 & 125 & 246 & 21.9 & 0.61 & 0.22 & 0.50 & $\begin{array}{c}1 \\
030\end{array}$ & $\mathrm{Co}$. & " \\
\hline & & & & & $1 \in .4$ & & 0.25 & 058 & 2.04 & & 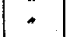 \\
\hline \multirow[t]{2}{*}{ (C) } & $s$ & 25 & 125 & 210 & Do & 0.61 & 0.37 & 059 & 1 & Co. & . \\
\hline & 5 & & 100 & 185 & $\mid \begin{array}{l}52.0 \\
164\end{array}$ & 061 & 6,40 & 0.57 & 2.30 & & Ara \\
\hline (d) & $s$ & 25 & 125 & |רוم| & I000 & 0 & 036 & 0.61 & 5 & Co. & " \\
\hline & \begin{tabular}{|l|}
62 \\
\end{tabular} & & 75 & $\frac{111}{124}$ & & 0.00 & 045 & 4176 & 255 & 54 & Ane. \\
\hline \multirow{2}{*}{$\begin{array}{l}\text { Retti } \\
\text { (a) }\end{array}$} & & 25 & & & 164 & 0.92 & 0.81 & 1.79 & 3 & & 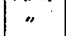 \\
\hline & 74 & & 100 & 153 & Jon & 1.02 & 1.10 & & 6.08 & $\mathrm{Co}$ & " \\
\hline \multirow[t]{2}{*}{ (b) } & 1 & 25 & 100 & 261 & & {$\left[\begin{array}{l}0.64 \\
092\end{array}\right.$} & 0.79 & & 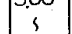 & & \\
\hline & 89 & & & & 40.8 & 1.02 & 1.02 & & 108 & co. & \\
\hline \multirow[t]{3}{*}{ Ret.(3) } & 90 & & 75 & & & 0.34 & 0.15 & 0.49 & & & " \\
\hline & $\xi$ & 25 & & 193 & & 0.61 & 0.25 & 060 & & co. & " \\
\hline & & & & & 32.8 & ror & 0.29 & 0.98 & 5,85 & & 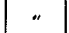 \\
\hline \multirow[t]{4}{*}{ Ret_(4) } & \begin{tabular}{|l|l|}
100 \\
\end{tabular} & & 100 & & & 0,34 & 027 & \begin{tabular}{|l|l|l}
1.00 \\
0.61
\end{tabular} & 3.10 & & $"$ \\
\hline & & & & & 18.8 & & & & & & \\
\hline & 1 & 25 & 100 & 240 & & 0.61 & 0.36 & $\{1.22$ & & Co. & " \\
\hline & 111 & & & & & 0,95 & 0,51 & 127 & 7.40 & & \\
\hline \multirow{3}{*}{$\begin{array}{l}\text { Ret15) } \\
\text { (a) }\end{array}$} & 112 & & $75^{\circ}$ & & & 0.31 & 0.19 & 1088 & 304 & & $\operatorname{cod}{ }^{-1}$ \\
\hline & 117 & 25 & 100 & 262 & 16.4 & 0.64 & 0.44 & 5.53 & 3 & co. & " \\
\hline & 718 & & 144 & & $\mid 46.1$ & $\begin{array}{l}0.56 \\
038\end{array}$ & 0.54 & $\begin{array}{l}4 \\
0.20 \\
0.72\end{array}$ & $\begin{array}{l}8.01 \\
2.97\end{array}$ & & Ara. \\
\hline (b) & 1 & 48 & $10 ?$ & 227 & 69.1 & 0.59 & 0.58 & 0.98 & 5 & Co. & $"$ \\
\hline \multirow[t]{5}{*}{ Ret,(6) } & 123 & & & & & & 0.10 & 1.02 & 081 & & Ara. \\
\hline & & & 100 & & 65.6 & 0.34 & 0.19 & 1.36 & & & \\
\hline & 8 & 50 & & 210 & & 0.61 & 0.42 & 1.48 & \& & Co. & " \\
\hline & & & 200 & & 131.3 & 0.95 & $\begin{array}{l}0.48 \\
0.53\end{array}$ & $\begin{array}{l}1.81 \\
233\end{array}$ & & & " \\
\hline & 137 & & & & & & 0.74 & 2.44 & 326 & & \\
\hline
\end{tabular}

App. Tabel 1 (b)

\begin{tabular}{|c|c|c|c|c|c|c|c|c|c|c|c|}
\hline & No: & $\underset{(\mathrm{Cm})}{\mathrm{D}}$ & $\begin{array}{l}2 \mathrm{a} \\
(\mathrm{cm})\end{array}$ & $\begin{array}{l}F C \\
k g t i n^{2}\end{array}$ & $\begin{array}{c}N \\
\text { ton }\end{array}$ & $(\%)$ & & $\rho_{w}(\%)$ & $\left\{\begin{array}{c}\mathrm{Ru} \\
\left(x \times 10^{-t}\right.\end{array}\right.$ & $\begin{array}{l}\text { Hoop } \\
\text { Type }\end{array}$ & $\begin{array}{l}\text { Shedr } \\
\text { Equ. }\end{array}$ \\
\hline Fet(7) & 138 & & 20 & & & & 0.23 & 0.78 & 1.67 & & Ara. \\
\hline (a) & 1 & 20 & 6 & 218 & 16.4 & 0.53 & 0.31 & 2.39 & 3 & Co. & \\
\hline (b) & 151 & & .75 & 240 & & 0.41 & 0.09 & 1.02 & 200 & & " \\
\hline & s & 25 & & . & 1888 & 1.24 & 0.22 & 1.42 & s & Có. & $"$ \\
\hline (C) & 167 & & 150 & 270 & & & $\begin{array}{l}0.51 \\
0.51\end{array}$ & $\begin{array}{l}2.12 \\
0.61\end{array}$ & 6.00 & & " \\
\hline (U) & 168 & & 50 & & 16.4 & . & 0.18 & 1.22 & 1.74 & & " \\
\hline & I & 25 & & 244.5 & & 0.61 & 0.27 & 1.27 & $s$ & Co. & " \\
\hline & 182 & & & & & o.95 & 0.45 & $\begin{array}{r}2.23 \\
2.44\end{array}$ & 6.40 & & . \\
\hline Ret.(8) & 183 & & 50 & 140 & 16.4 & 0.31 & 1020 & 048 & 280 & & " \\
\hline & I & 25 & & & & 0.64 & 021 & 061 & & Co & $"$ \\
\hline & 187 & & 100 & 180 & 32,8 & 0,96 & lo30 & 1094 & $100^{\circ}$ & & $"$ \\
\hline$(19)$ & 188 & & .50 & 270 & 16.4 & $\overline{0.46}$ & 0.27 & 1,24 & 2.17 & SU. & “ \\
\hline & 1 & 25 . & & & & 0.82 & 036 & 1.49 & s & Sp. & \\
\hline & 202 & & 100 & 322 & 328 & 1.28 & -1.12 & 1.53 & 6.18 & co. & \\
\hline (b) & 200 & & 50 & 272 & 16.4 & 0.69 & 0.27 & 1.22 & 3.00 & & \\
\hline & 207 & $<0$ & 100 & 1329 & 328 & 1.12 & 0,36 & 1.54 & 589 & Sp. & \\
\hline Reț10 & 208 & 25 & 100 & 206.4 & 16.4 & 0.34 & 0.07 & & 1.12 & Co. & Ans. \\
\hline if(17) & 209 & 25 & 50 & 473 & 16.4 & $\overline{0.34}$ & 0.21 & 0.58 & +2.00 & $\mathrm{Co}$ & $"$ \\
\hline & s & & & & & & 10.20 & 0.76 & $s$ & & " \\
\hline & 216 & & 100 & & 32.8 & 0.95 & b.29 & 0.91 & 4.80 & & $"$ \\
\hline etsi & 217 & 25 & 100 & 165 & 21.8 & 0.61 & 0.27 & & 2.30 & Co. & 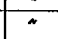 \\
\hline & -222 & & & & & & 0.41 & & -250 & & \\
\hline Ret.113 & 223 & & & 206 & 78.6 & 0.64 & 0.40 & 1,30 & 2.00 & & 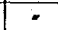 \\
\hline & $\begin{array}{c}1 \\
229 \\
\end{array}$ & 35 & 175 & $\begin{array}{c}5 \\
233\end{array}$ & $\begin{array}{l}87.7 \\
94.2 \\
\end{array}$ & 1.00 & $\begin{array}{l}0.79 \\
1.00\end{array}$ & & (5. & D.Sp: & * \\
\hline Refis & 230 & 25 & 50 & 2736 & 16.4 & 0.61 & 0,45 & 1.09 & 2.30 & $\mathrm{Cl}$. & 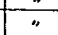 \\
\hline (c) & $\begin{array}{r}-233 \\
234\end{array}$ & & 100 & & 32.8 & & 0.56 & 234 & $\sim 3.50$ & & $"$ \\
\hline (D) & 3 & 40 & 160 & 287.2 & 480 & 0.61 & 1.30 & 1.41 & 3.56 & Sp. & $\cot$ \\
\hline & 241 & & 100 & 314.5 & 128.0 & 0.99 & 1.38 & $\begin{array}{l}1.47 \\
1.67\end{array}$ & 1739 & Sú. & N \\
\hline (C) & & & 120 & 240 & 800 & 0,61 & 0.95 & 1.77 & 3,61 & We. & 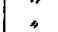 \\
\hline & & 40 & & & 96.0 & & 1.71 & 2.07 & & & \\
\hline & 2 & & 160 & 277 & 128.0 & 0.99 & 122 & & 9.09 & Sp. & " \\
\hline & $\begin{array}{l}246 \\
\sim 240\end{array}$ & 25 & 150 & 1292 & 22.8 & 0.34 & 0.21 & 0.54 & 2.45 & Co. & Ara. \\
\hline $\mathrm{Re}$ & 250 & .75 & 45 & 199 & 9.40 & \begin{tabular}{|l|}
1.13 \\
\end{tabular} & 0.42 & & 1,98 & Sp. & Cod. \\
\hline & -252 & & & $\sim 230$ & 106 & & & & $\sim 300$ & & in \\
\hline $\operatorname{Ret}(77)$ & 253 & & & & & 0.42 & 0.75 & 1.40 & 1.47 & We. & \\
\hline & & 30 & 1720 & 1183 & $\begin{array}{l}41.0 \\
47.3\end{array}$ & 0.64 & $\mid 0.85$ & $\begin{array}{l}1.02 \\
1.69\end{array}$ & 588 & $\begin{array}{l}\text { Sp. } \\
\text { Su. }\end{array}$ & $"$ \\
\hline
\end{tabular}




\section{鉄筋コンクリート柱の変形限界值について (梗概)}

正会員沜 津 孝 之*

鉄筋コンクリート柱の水平力に対寸る变形能を明らか にすることは，耐震安全上並びに設計上解決すべき重要 な課題の一つである。本論文では, 既往の諸実験結果を 用いて，柱の変形限界值に関する一つの推定式を提案し ている。

1968 年の十勝沖地震以来, 鉄管 コンクリート柱の水 平抵抗に関する実験的研究は数多くなされ, 特に 72 年 から開始された“綜合プロジェクト”の一連の実験は, とりあつかった試験体の数が大きいことと同時に，各試 験体に; 破壊に至るまでに計 50 回程度の正負繰返しの 水平力を加えているの特徵的である。またこれらの研究 では最大耐力に達したあと, それ以降での振幅に打ける 第 1 回目の荷重または第 10 回目の荷重が, 最大耐力の $80 \%$ または $50 \%$ 以下になる洔の変形を変形限界值と定 義している (図一-1 参照)。本論文でもこの定義に従っ たものを柱の変形限界值と考え, その值が帯筋比をはじ めとして, 主筋比や軸圧比あるいはせん断スパン比によ ってどのように変化するかを調べた。取扱った試験体の 総数は綜合プロジェクト以外のものも含め, 計 263 体で 要る。これら試験体に関する各種変数の範囲は表一1に 示す通りである。柱の変形限界值は, 帯筋比, 主筋比, 軸圧比, せん断スパン比だけでなく，柱の寸法や，同じ 带筋比でも, 帯筋の種類 (スパイラルやサブタイや在来 型）によって，また同じ主筋比でも，主筋の種類（異形 と丸鋼）等によって影響をうけることが考えられる。し かし本論文では，大きな傾向を把握することを目的とし ているので, 带筋比, 主筋比, 軸圧比, せん断スパンの 4 つの変数の影響をみることに限定した。通常柱は曲げ 降伏型に設計されるが，これら試験体でも原則としてそ のよらに設計されている。用いられた，曲げ耐力計算式 は，すべて (1) 式と考えてよい。一方せん断耐力計算式 は規準式また流川下限式あるいは修正大野荒川式であ る。 3 つのらち修正大野荒川式が軸力を考慮したせん断 耐力を評価できるので，この式にもとづいてすべての 試験体のせん断耐力を計算し，(1)：式の曲げ耐力計算值 と比較した。図一4 はその比率の範囲を示したもので, 図一5 はその分布状態を例示したものである。結局, 本 論文でとり上げた試験体は殆んどす心゙て計算上曲げ耐力 以上のせん断耐力を有していることがわかった。図一6

*庄島大学 助教授・工博

(㗁和 55 年 6 月 3 日本稿受理 - 討論期限昭和 56 年 10 月末日)
の各図は各柱の変形限界值をせん断スパン比每に示した ものである。縦軸には軸圧比がとってある。各図には実 験值の下限值にほぼ相当する右下りの直線が示してある が，それらは図一2 と図一7 及び本文に示寸 3 条件にも とづいて導いた (3) 式を表わしている。またこれらの図 のプロッ市值はそれぞれ $p_{w} / p_{t}$ (帯筋比/主筋比) 值で分 類してある。なお $p_{w}$ 值だけの分類も試みたが，後に図 -9, 10 に関連して, 図一 8 に示すように, $P_{w}$ 值その ものの效果については, 法則的な傾向を見出すことがで きなかった。すなわち主筋比が大きい柱は，同一の変形 能をうるためには，より多くの带筋を用いる必要がある ことを示している。図一6 の各プロット值の理論線（右 下りの直線）との水平距離はいわば $p_{w} / p_{t}$ 值の効果を あらわすものであるが，それらを縦軸にプロットしたの が, 図-10 である。横軸はいゔれも $\sqrt{p_{w} / p_{t}}$ 值をとっ ている。実験值は各図に示す各折れ線（実線）のまわり に分布しており，それら各折れ線は（4)（9）式に示す ように表現できる。この (4) (6). 式壮対数值である から，それを考慮して (3) 式を搪張すると， $\sqrt{p_{w} / p_{t}}$ 值の効果を入れた（10）式がえられる。この式によって 奉験值の平均的な值を推定することができる。しかし耐 震設計等, 安全率を見込む立場からは, 図一10の各図に 示すように，各折れ線 (実線)をそのまま下方にスライ ドさせた折れ線 (点線)を用いることが望まもしい。こ れらは（11）および(12) 式で表わされ，実験值総数に 対する不合格率はそれぞれ $14.8 \%$ および $4.6 \%$ であ る。なお上記 3 式は, 降伏域でのコンクリート限界歪の 与えた值の大小だけが異なるだけで, $\sqrt{p_{w} / p_{t}}$ 值による 効果はすべて同一で，それによってコンクリートの限 界歪が，同じょうに増加してゆくとも解釈できる。図一 $11,12,13$ は带筋の種類や, せん断耐力の曲げ耐力に対 する割合 $\left(Q_{s} / Q_{m}\right)$ の大小等の影響を, せん断スパン比 2.0 の場合について示したものである。しかしこれらの 変数による効果に関しては, 結論を導き出すまでには至 っていない。な打図一14の各図に, 変形限界值そのも のと $Q_{s} / Q_{m}$ 值との関係をみるためにプロットを試み た。当然乍ら，あまり関連性以みられない。最後に，現 行の規準書にある提案式（本文の 13）との比較を行い， 本論文の提案式（本文 10 12) がより適切であること をのべた。 